\title{
Hsp70 gene polymorphisms in farmed marine shrimp Litopenaeus vannamei populations exposed to white spot disease and infectious myonecrosis
}

\author{
A.L. Ferreira Jr' ${ }^{1,2}$, R. Maggioni ${ }^{3}$, D. Conceição ${ }^{2}$, L.M. Perazzolo ${ }^{1}$ and \\ R.L. Petersen ${ }^{2}$ \\ ${ }^{1}$ Laboratório de Imunologia Aplicada à Aquicultura, \\ Departamento de Biologia Celular, \\ Universidade Federal de Santa Catarina, Florianópolis, SC, Brasil \\ ${ }^{2}$ Laboratório de Genética Marinha e Melhoramento de Organismos Aquáticos, \\ Centro de Estudos do Mar, Universidade Federal do Paraná, \\ Pontal do Sul, PR, Brasil \\ ${ }^{3}$ Centro de Diagnóstico de Enfermidades de Organismos Aquáticos, \\ Instituto de Ciências do Mar, Universidade Federal do Ceará, \\ Fortaleza, CE, Brasil \\ Correspondig author: L.M. Perazzolo \\ E-mail:1.m.perazzolo@ufsc.br
}

Genet. Mol. Res. 16 (2): gmr16029668

Received March 14, 2017

Accepted April 19, 2017

Published May 4, 2017

DOI http://dx.doi.org/10.4238/gmr16029668

Copyright (C) 2017 The Authors. This is an open-access article distributed under the terms of the Creative Commons Attribution ShareAlike (CC BY-SA) 4.0 License.

ABSTRACT. Single nucleotide polymorphisms (SNPs) are the
best genetic markers for associative studies of the immune system
in invertebrates. In the marine shrimp Litopenaeus vannamei, SNPs
linked to disease resistance have been reported for some genes, such as
hemocyanin, anti-lipopolysaccharide factor, and heat-shock protein 70
(Hsp70). In the present study, polymorphisms in the Hsp70 gene were
investigated among three commercial L. vannamei populations bred

Genetics and Molecular Research 16 (2): gmr16029668 
in Northeast and South Brazil. The first population withstood a strong white spot disease outbreak; the second population suffered extended exposure to infectious myonecrosis; the third population was a high health population, which was experimentally infected with white spot syndrome virus (WSSV) in the present study. All five previously known SNPs (C661A, T712C, C782T, C892T, and C1090T) were detected in the coding region of Hsp70, by Sanger sequencing of 119 shrimp. Significant differences in genetic and genotype frequencies among populations were observed for C661A, C892T, and C1090T. In the population submitted to WSSV challenge, no frequency differences were found between dead and surviving shrimp groups. These results indicate that the Hsp70 polymorphisms described here cannot be associated with WSSV tolerance. However, significant frequency differences were observed for the population exposed to infectious myonecrosis virus. This is the first time that L. vannamei Hsp 70 gene polymorphisms were studied in correlation with these important shrimp viruses.

Key words: SNP; Chaperone; Shrimp; WSSV; IMNV

\section{INTRODUCTION}

Heat-shock proteins (HSPs) are chaperones known to be induced particularly under environmental stress when they actively refold and prevent denaturation of other proteins (Shekhar and Ponniah, 2015). HSPs may exceed $15 \%$ of total intracellular proteins in animals subjected to stress, such as temperature shifts, heavy metals, hypoxia, and infection (Srivastava, 2002). One of the most studied HSPs is the Hsp70, for its ubiquity and essential role in the cell (Morano, 2007). In Litopenaeus vannamei the transcription of the $H s p 70$ gene is induced at $32^{\circ} \mathrm{C}$ during white spot syndrome virus (WSSV) infection, suggesting a functional role of HSPs in suppressing virus replication and reducing mortality in WSSV-infected shrimps (Lin et al., 2011).

In the past thirty years, viral diseases, such as Taura syndrome, white spot disease, and infectious myonecrosis, caused great impact on shrimp farming worldwide (Lightner et al., 2012). WSSV alone is considered responsible for 10 billion dollar losses in Asia (Karunasagar and Ababouch, 2012). WSSV caused the collapse of Southern Brazil shrimp farming in 2005 and has now reached high production areas in the Northeast (Santos et al., 2013). Infectious myonecrosis virus (IMNV) caused a sharp production break in Brazil, during 2004, and spread to Asia, since then (Senapin et al., 2007). One of the strategies adopted by the shrimp industry to counter the threat posed by viral diseases was to develop shrimp populations with specific characteristics, such as specific pathogen-free and specific pathogen-resistant (Huang et al., 2012; Moss et al., 2012). Quantitative trait loci, development and marker-assisted selection are likely to boost these strategies in the next few years, for farmed penaeids (Robinson et al., 2014; Yu et al., 2014).

Single nucleotide polymorphisms (SNPs) hold the highest potential for the development of animal quantitative trait loci, due to its abundance and ubiquity (Vignal et al., 2002; Ciobanu et al., 2010). SNPs are single-base-pair changes in the genomic DNA sequence where the frequency of the most abundant allele is lower than 99\% (Brookes, 1999). In L. vannamei, some SNPs were found to be associated with resistance to pathogens, such as those observed

Genetics and Molecular Research 16 (2): gmr16029668 
in the C-terminus of hemocyanin (Zhao et al., 2012), in the anti-lipopolysaccharide factor (nLvALF1; Liu et al., 2014), and in Hsp70 (Zeng et al., 2008). Synonym base substitutions in the $L$. vannamei $H s p 70$ gene seem to be correlated with Taura syndrome virus (TSV) resistance (Zeng et al., 2008). In the present study, we examine Hsp70 SNPs in Brazilian commercial shrimp populations historically exposed to severe natural infection by WSSV and IMNV. This is the first time that $H s p 70$ gene polymorphisms are studied in correlation with these important shrimp viruses.

\section{MATERIAL AND METHODS}

\section{Sampling and origin of the genetic material}

Three L. vannamei populations bred in Brazil were sampled. The first population (identified henceforth as Lv-A) was from southern Brazil (Imbituba, Santa Catarina, $\left.28^{\circ} 13^{\prime} 43^{\prime \prime} \mathrm{S}, 48^{\circ} 39^{\prime} 58^{\prime \prime} \mathrm{W}\right)$, formed by animals which survived a severe WSSV outbreak in the region (Santos et al., 2013). The second population (Lv-B) was from southern Brazil as well but was formed by animals originating from specific pathogen-free populations introduced in Santa Catarina State for commercial purposes. Population Lv-B was certified as free from WSSV and was kept under high-biosafety laboratory conditions at Laboratório de Camarões Marinhos (LCM), Universidade Federal de Santa Catarina (UFSC). The third population (Lv-C) was formed by animals from a commercial breeding program with strong selection pressure from infectious myonecrosis, located in Northeastern Brazil (Mello et al., 2011). Population Lv-C was confirmed as negative for WSSV and IHHNV (infectious hypodermal and hematopoietic necrosis virus) after the first spawning of each annual reproduction cycle. In all instances, muscle samples were taken from the first abdominal segment of each animal. Samples were individually preserved in $96 \%$ ethanol and stored at $-20^{\circ} \mathrm{C}$ until processing.

\section{Viral challenge}

The experimental WSSV infection was conducted on 84 juvenile L. vannamei $(12 \pm 2$ g) from population Lv-B, obtained at LCM. The animals were initially acclimated for 8 days in 40 - L constantly aerated tanks $\left(23^{\circ} \pm 4^{\circ} \mathrm{C}\right.$; salinity $32-34 \%$ ), at a density of 10 animals per tank. Before infection, each animal was individually tested for the presence of WSSV through nested polymerase chain reaction (PCR) (Lo et al., 1996). The animals were fed pelletized commercial feed provided ad libitum once a day. Approximately $30 \%$ of the water was renewed daily. Only male and female animals at the intermolt stage were used in the experiments. Experimental infections were carried out by intramuscular injection of $50 \mu \mathrm{L}$ standardized WSSV inoculum (500 viral particles in total), into the shrimp dorsal region (Goncalves et al., 2014). Mortality was checked three times a day, over 15 days of the viral challenge. Muscle samples were taken from animals found dead, and from all surviving animals at the end of the experiment. Samples were stored in $70 \%$ ethanol at $-20^{\circ} \mathrm{C}$ until processing.

\section{Genomic DNA extraction and amplification of the Hsp70 gene}

Genomic DNA was extracted from approximately $20 \mathrm{mg}$ muscle tissue from 119 animals, using a commercial kit (Axygen Biosciences; Norgen Biotek Corp.) according to 
manufacturer's specifications. The 1119-bp fragment (position 475 to 1594) of the $H s p 70$ gene (Figure 1) was amplified using primers 5'-TCT CGG GTC TGA ATG TGC-3' and 5'-GAA ATA CGG TCC CTC TGC-3' (Zeng et al., 2008). PCRs were carried out in a final volume of $10 \mu \mathrm{L}$ containing $50 \mathrm{ng}$ genomic DNA; $1.5 \mathrm{mM} \mathrm{MgCl} ; 200 \mu \mathrm{M}$ each dNTP; $0.6 \mu \mathrm{M}$ each primer; $2.5 \mathrm{U} \mathrm{GoTaq}^{\circledR}$ G2 Hot Start Polymerase (Promega, USA) and 1X Promega proprietary buffer. PCRs were performed on a Swift MaxPro (ESCO) thermal cycler and comprised an initial denaturation step of $95.0^{\circ} \mathrm{C}$ for $2 \mathrm{~min}$; followed by 35 cycles of $94^{\circ} \mathrm{C}$ for $30 \mathrm{~s}, 56^{\circ} \mathrm{C}$ for $45 \mathrm{~s}$ and $72^{\circ} \mathrm{C}$ for $1 \mathrm{~min}$; followed by a final elongation step of $72.0^{\circ} \mathrm{C}$ for $10 \mathrm{~min}$.

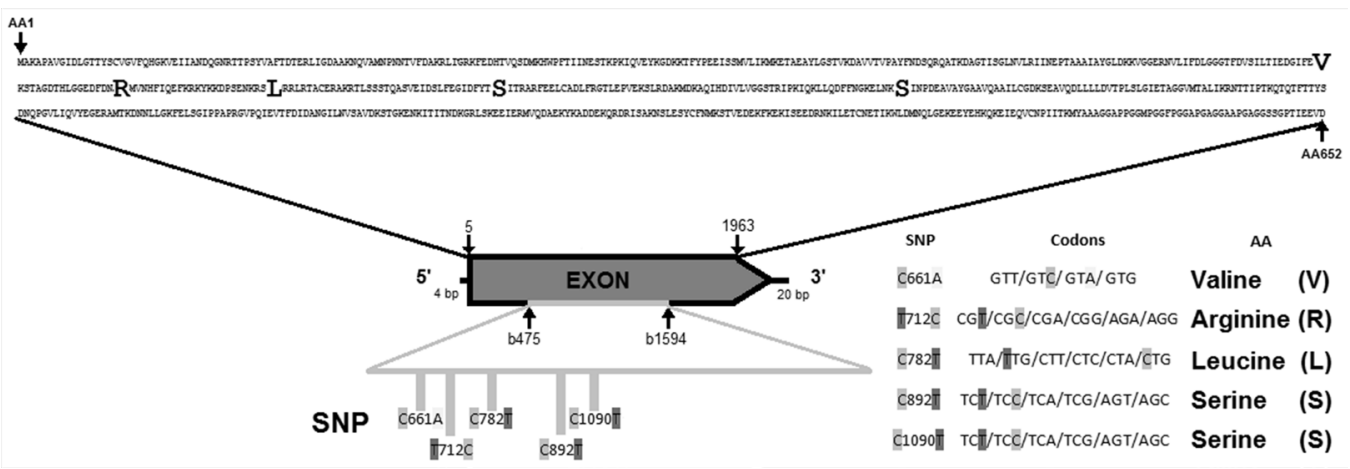

Figure 1. SNP distribution in the Hsp70 gene from Litopenaeus vannamei. The light gray line represents the PCR amplicon; number near arrows indicate base or amino acid position relative to the reference sequence AY645906; amino acids corresponding to the synonymous SNPs are emphasized.

\section{SNP genotyping and analysis}

The identification of SNPs was performed by direct Sanger sequencing of PCR amplicons using BigDye ${ }^{\circledR}$ Terminator v3.1 Cycle Sequencing kit (Applied Biosystems ${ }^{\mathrm{TM}}$ ), following the manufacturer's instructions. Sequencing reactions were purified by precipitation in isopropanol/ethanol (Sambrook et al., 1989), denatured at $95^{\circ} \mathrm{C}$ for $5 \mathrm{~min}$ in $10 \mu \mathrm{L}$ formamide and read on a 3500 Genetic Analyzer (Applied Biosystems ${ }^{\mathrm{TM}}$ ). Each amplicon was sequenced in both directions. Sequences were checked manually using Sequencing Analysis v. 5.4 (Applied Biosystems $^{\mathrm{TM}}$ ). For SNP genotyping, only polymorphisms with quality values of 10 or higher, where flanking bases presented quality values of 30 or higher, were considered. Genotypes were checked against the complete L. vannamei Hsp 70 gene sequence (GenBank accession No. AY645906). Allele and genotype frequencies, exact tests for Hardy-Weinberg and linkage disequilibrium, $F_{\mathrm{IS}}$ and $F_{\mathrm{ST}}$ and $G_{\mathrm{ST}}$ were calculated using GENEPOP Online v. 4.2 (Rousset, 2008) and GenAlEx 6.5 (Peakall and Smouse, 2012). Allele frequencies were compared by $\chi^{2}$ pairwise tests, using STATISTICA 10.0 (StatSoft Ltd., 2012). Genetic distances (Nei, 1977) were calculated using the GenAlEx 6.5 program (Peakall and Smouse, 2012).

\section{RESULTS}

All five previously reported SNPs (C661A, T712C, C782T, C892T, and C1090T) were identified among sequences of 119 shrimp. Significant frequency differences were detected in 
three loci for population Lv-C (Table 1). Linkage disequilibrium was observed only between $\mathrm{C} 892 \mathrm{~T}$ and $\mathrm{C} 1090 \mathrm{~T}(\mathrm{P}<0.01)$.

\begin{tabular}{|c|c|c|c|c|}
\hline \multirow[t]{2}{*}{ SNP } & \multirow[t]{2}{*}{ Allele } & \multicolumn{3}{|c|}{ Allele frequencies $(\mathrm{N})$} \\
\hline & & Lv-A & Lv-B & Lv-C \\
\hline \multirow[t]{3}{*}{ C661A } & $\mathrm{C}$ & 0.903 & 0.944 & $0.984 *$ \\
\hline & A & 0.097 & 0.056 & $0.016^{*}$ \\
\hline & & $(36)$ & $(45)$ & $(32)$ \\
\hline \multirow[t]{3}{*}{$\mathrm{T} 712 \mathrm{C}$} & $\mathrm{T}$ & 0.051 & 0.089 & 0.062 \\
\hline & $\mathrm{C}$ & 0.949 & 0.911 & 0.938 \\
\hline & & (39) & $(45)$ & $(32)$ \\
\hline \multirow[t]{3}{*}{$\begin{array}{l}\mathrm{C} 782 \mathrm{~T} \\
\end{array}$} & $\mathrm{C}$ & 0.975 & 0.977 & 1.000 \\
\hline & $\mathrm{T}$ & 0.025 & 0.023 & 0.000 \\
\hline & & $(40)$ & $(44)$ & $(32)$ \\
\hline \multirow[t]{3}{*}{ C892T } & $\mathrm{C}$ & 0.695 & 0.733 & $0.591 * *$ \\
\hline & $\mathrm{T}$ & 0.305 & 0.267 & $0.409^{* *}$ \\
\hline & & $(41)$ & $(45)$ & (33) \\
\hline \multirow{3}{*}{ C1090T } & $\mathrm{C}$ & 0.829 & $0.944 *$ & $0.636^{* * *}$ \\
\hline & $\mathrm{T}$ & 0.171 & $0.056^{*}$ & $0.364^{* *}$ \\
\hline & & $(38)$ & $(45)$ & (33) \\
\hline
\end{tabular}

Significant differences in allele frequencies: $* \mathrm{P}<0.05 ; * * \mathrm{P}<0.01 . \mathrm{N}=$ sample size.

The average observed heterozygosity was lower in populations Lv-A $\left(H_{\mathrm{O}}=0.127\right)$ and Lv-B $\left(H_{\mathrm{O}}=0.062\right)$ when compared with $\mathrm{Lv}-\mathrm{C}\left(H_{\mathrm{O}}=0.243\right)$. The average expected heterozygosity ranged from $16.1 \%( \pm 1.3)$ to $21.9 \%( \pm 2.4)$. These mean heterozygosity estimates were inflated by the linkage between C892T and C1090T. However, observed heterozygosity values for Lv-C were higher for each of the individual loci (Table 2). Southern populations $(\mathrm{Lv}-\mathrm{A}$ and $\mathrm{Lv}-\mathrm{B})$ were not in Hardy-Weinberg equilibrium $(\mathrm{P}<0.05)$ in 60 and $100 \%$ of the tests, respectively (Table 2 ). $F_{\text {IS }}$ values for population Lv-A and Lv-B were high, which might indicate intense inbreeding.

\begin{tabular}{|c|c|c|c|c|c|c|}
\hline \multirow{2}{*}{\multicolumn{2}{|c|}{ Population (N) }} & \multicolumn{5}{|c|}{ Locus } \\
\hline & & C661A & $\mathrm{T} 712 \mathrm{C}$ & $\mathrm{C} 782 \mathrm{~T}$ & $\mathrm{C} 892 \mathrm{~T}$ & $\mathrm{C} 1090 \mathrm{~T}$ \\
\hline \multirow{5}{*}{$\begin{array}{l}\text { Lv-A } \\
(41)\end{array}$} & $H_{\mathrm{O}}$ & 0.028 & 0.000 & 0.000 & 0.317 & 0.289 \\
\hline & $H_{\mathrm{E}}$ & 0.176 & 0.097 & 0.049 & 0.424 & 0.284 \\
\hline & $F_{\text {IS }}$ & 0.842 & 1.000 & 1.000 & 0.252 & -0.021 \\
\hline & HWE & 0.000 & 0.000 & 0.000 & 0.107 & 0.898 \\
\hline & $\mathrm{N}$ & 36 & 39 & 40 & 41 & 38 \\
\hline \multirow{5}{*}{$\begin{array}{l}\text { Lv-B } \\
(45)\end{array}$} & $H_{\mathrm{O}}$ & 0.022 & 0.044 & 0.000 & 0.178 & 0.067 \\
\hline & $H_{\mathrm{E}}$ & 0.105 & 0.162 & 0.044 & 0.391 & 0.105 \\
\hline & $F_{\text {IS }}$ & 0.788 & 0.726 & 1.000 & 0.545 & 0.365 \\
\hline & HWE & 0.000 & 0.000 & 0.000 & 0.000 & 0.014 \\
\hline & $\mathrm{N}$ & 45 & 45 & 44 & 45 & 45 \\
\hline \multirow{5}{*}{$\begin{array}{l}\mathrm{Lv-C} \\
\text { (33) }\end{array}$} & $H_{\mathrm{O}}$ & 0.031 & 0.125 & 0.000 & 0.697 & 0.364 \\
\hline & $H_{\mathrm{E}}$ & 0.031 & 0.117 & 0.000 & 0.483 & 0.463 \\
\hline & $F_{\text {IS }}$ & -0.016 & -0.067 & 1.000 & -0.442 & 0.214 \\
\hline & HWE & 0.928 & 0.706 & - & 0.011 & 0.218 \\
\hline & $\mathrm{N}$ & 32 & 32 & 32 & 33 & 33 \\
\hline
\end{tabular}

$H_{\mathrm{O}}$, observed heterozygosity; $H_{\mathrm{E}}$, expected heterozygosity; $F_{\mathrm{IS}}$, inbreeding index; HWE, Hardy-Weinberg equilibrium probability; N, sample size.

Genetics and Molecular Research 16 (2): gmr16029668 
Pairwise $F_{\mathrm{ST}}$ and $G_{\mathrm{ST}}$ estimates per loci varied widely ( 0.000 to 0.258$)$ reflecting the distribution of allele frequencies among populations. The average values observed $\left(F_{\mathrm{ST}}=\right.$ $\left.0.042 ; G_{\mathrm{ST}}=0.031\right)$ were strongly influenced by the frequencies observed at loci C892T and C1090T, and the linkage between them. Considering this observation, $F_{\mathrm{ST}}$ and $G_{\mathrm{ST}}$ estimates should be taken only as an indication of relative genetic differentiation between the studied populations (Table 3). Likewise, the genetic distance $(D)$ observed between populations was small, and suggested closer proximity between the Lv-A and Lv-B Southern populations when compared with Lv-C.

Table 3. Pairwise indexes of population differentiation $\left(F_{\mathrm{ST}}, G_{\mathrm{ST}}\right)$ and genetic distance $(D)$ among the studied populations.

\begin{tabular}{l|l|c|c|c}
\hline \multicolumn{2}{l|}{} & $F_{\text {ST }}$ & $G_{\text {ST }}$ & $D$ \\
\hline Lv-A & Lv-B & $\mathbf{0 . 0 2 8}$ & 0.001 & 0.004 \\
\hline Lv-A & Lv-C & $\mathbf{0 . 0 3 2}$ & $\mathbf{0 . 0 3 4}$ & 0.014 \\
\hline Lv-B & Lv-C & $\mathbf{0 . 0 9 1}$ & $\mathbf{0 . 0 9 6}$ & 0.029 \\
\hline
\end{tabular}

Numbers in bold indicate $F_{\mathrm{ST}}$ and $G_{\mathrm{ST}}$ values significantly different from zero $(\mathrm{P}<0.05)$.

The viral challenge resulted in $84.5 \%$ mortality after 15 days. However, no significant differences were observed in gene and genotype frequencies between the surviving and dead groups of shrimp, in any of the five scored SNPs $(P>0.05)$. No significant differences were observed between either of these groups and Lv-B, as well $(\mathrm{P}>0.05)$.

\section{DISCUSSION}

Genetic diversity is important for shrimp breeding programs because it preserves the opportunity for genetic improvement. Nevertheless, variability loss in captive shrimp populations is frequently observed due to founder and inbreeding effects (Benzie, 2009; Cook et al., 2009; Andriantahina et al., 2013). The populations evaluated in this study showed evidence of different levels of genetic diversity, as revealed by $H s p 70$ gene polymorphisms. Lower observed heterozygosity among SNPs from populations Lv-A and Lv-B (Southern Brazil) might be associated with higher inbreeding. On the other hand, the higher observed heterozygosity found in population Lv-C (Northeastern Brazil) was likely the result of a genetic program with controlled crossings. This genetic improvement program has pedigree control and focuses on IMNV resistance, which may have preserved genetic variability after successive generations in population Lv-C (Mello et al., 2011). Differences in founder pool and germplasm management were likely reasons for the significant allele frequency differences observed among the populations surveyed here. However, population Lv-C was under strong selective pressure for IMNV resistance; therefore, a possibility remains that some of the studied SNPs were correlated to this attribute.

The inbreeding index $\left(F_{\mathrm{IS}}\right)$ showed higher values in populations Lv-A and Lv-B as compared to population Lv-C. A moderate to high level of inbreeding seems to be common in Brazilian shrimp farming. Using microsatellites, Lima et al. (2008) reported $F_{\text {IS }}$ ranging from 013 to 0.39 in L. vannamei from Bahia State (Northeastern Brazil). Other studies conducted with $L$. vannamei populations from Brazilian post-larvae production laboratories showed $F_{\text {Is }}$ ranging from 0.00 to 0.38 (Luvesuto et al., 2007; Lima et al., 2010; Maggioni et al., 2013). Considering the history of geographical isolation, the higher $F_{\text {IS }}$ values observed in populations Lv-A and Lv-B from Southern Brazil are likely related to inbreeding.

Genetics and Molecular Research 16 (2): gmr16029668 
The index of population differentiation $\left(F_{\mathrm{ST}}\right)$ is an estimator of genetic differentiation in structured populations (Nei, 1977). Reliable $F_{\mathrm{ST}}$ estimates require at least random mating and allele frequency equilibrium at subpopulation level, conditions seldom met in aquaculture conditions. Nevertheless, $F_{\mathrm{ST}}$ has been widely used to evaluate genetic relationships among cultivated populations. For instance, low genetic differentiation $\left(F_{\mathrm{ST}}=0.015\right)$ was reported among six post-larvae producers from Mexico (Perez-Enriquez et al., 2009). In Brazil, little $\left(F_{\mathrm{ST}}=0.000\right)$ to moderate $\left(F_{\mathrm{ST}}=0.175\right)$ differentiation was observed among nine post-larvae laboratories (Maggioni et al., 2013). In the present study, $F_{\mathrm{ST}}$ and $G_{\mathrm{ST}}$ values represented only an estimate of relative differentiation among populations. They suggested that populations Lv-A and Lv-B were genetically closer. This relationship was indicated by the values of genetic distance $(D)$ as well. These results agreed with the history of the studied populations. Southern populations ( $\mathrm{Lv}-\mathrm{A}$ and $\mathrm{Lv}-\mathrm{B}$ ) are geographically far away from Lv-C. Populations Lv-A and Lv-B likely descend from a single founder stock, which was split during a severe WSSV outbreak. For at least 10 years, population Lv-A remained exposed to WSSV, while Lv-B was kept clean from this virus. Such scenario seems sufficient to explain the small genetic differences found and its distribution among the studied populations.

Association between $H s p 70$ gene polymorphisms and resistance to TSV among Asian commercial L. vannamei populations has been reported (Zeng et al., 2008). In addition to that, induction of $H s p 70$ gene transcription at $32^{\circ} \mathrm{C}$ during WSSV infection suggests a connection between this gene and WSSV resistance in shrimp (Lin et al., 2011). In the present study, we have challenged a virus-free population with WSSV, and no significant genetic differences were found between the dead and surviving groups. Therefore, no evidence was found here of any association between Hsp70 SNPs and WSSV resistance. However, the significant differences found in population $\mathrm{Lv}-\mathrm{C}$, exposed to IMNV, remain to be explored.

\section{ACKNOWLEDGMENTS}

Research supported by FINEP (Financiadora de Estudos e Projetos) within the project RECARCINA. Graduate and post-graduate scholarships were provided by CNPq (Conselho Nacional de Desenvolvimento Científico e Tecnológico) and CAPES (Coordenadoria de Aperfeiçoamento de Pessoal de Nível Superior). The authors would like to thank the team at Laboratório de Camarões Marinhos (LBM) for providing the shrimp from population Lv-B; the supporting staff and students at CEM (Centro de Estudos do Mar), UFPR; CCB (Centro de Ciências Biológicas), UFSC, and LABOMAR (Instituto de Ciências do Mar), UFC.

\section{REFERENCES}

Andriantahina F, Liu X, Feng T and Xiang J (2013). Current status of genetics and genomics of reared penaeid shrimp: information relevant to access and benefit sharing. Mar. Biotechnol. (NY) 15: 399-412. https://doi.org/10.1007/ s10126-013-9500-9

Benzie JAH (2009). Use and exchange of genetic resources of penaeid shrimps for food and aquaculture. Rev. Aquacult. 1: 232-250. https://doi.org/10.1111/j.1753-5131.2009.01018.x

Brookes AJ (1999). The essence of SNPs. Gene 234: 177-186. https://doi.org/10.1016/S0378-1119(99)00219-X

Ciobanu DC, Bastiaansen JWM, Magrin J, Rocha JL, et al. (2010). A major SNP resource for dissection of phenotypic and genetic variation in Pacific white shrimp (Litopenaeus vannamei). Anim. Genet. 41: 39-47. https://doi.org/10.1111/ j.1365-2052.2009.01961.x

Cook J, Gitterle T, Salazar M and Morten-Rye M (2009). Breeding for disease resistance of Penaeid shrimps. Aquaculture 286: 1-11. https://doi.org/10.1016/j.aquaculture.2008.09.011

Genetics and Molecular Research 16 (2): gmr16029668 
Goncalves P, Guertler C, Bachère E, de Souza CR, et al. (2014). Molecular signatures at imminent death: hemocyte gene expression profiling of shrimp succumbing to viral and fungal infections. Dev. Comp. Immunol. 42: 294-301. https:// doi.org/10.1016/j.dci.2013.09.017

Huang Y, Yin Z, Weng S, He J, et al. (2012). Selective breeding and preliminary commercial performance of Penaeus vannamei for resistance to white spot syndrome virus (WSSV). Aquaculture 364-365: 111-117. https://doi. org/10.1016/j.aquaculture.2012.08.002

Karunasagar I and Ababouch L (2012). Shrimp viral diseases, import risk assessment and international trade. Indian J. Virol. 23: 141-148. https://doi.org/10.1007/s13337-012-0081-4

Lightner DV, Redman RM, Pantoja CR, Tang KFJ, et al. (2012). Historic emergence, impact and current status of shrimp pathogens in the Americas. J. Invertebr. Pathol. 110: 174-183. https://doi.org/10.1016/j.jip.2012.03.006

Lima APS, Santos ACL, Dantas HL, Gomes-Filho MA, et al. (2008). Genetic monitoring of broodstocks of the marine shrimp Litopenaeus vannamei in a closed rearing system in Pernambuco, Brazil. Aqua Res 39: 1461-1466. https:// doi.org/10.1111/j.1365-2109.2008.02022.x

Lima APS, Silva SMBC, Oliveira KKC, Maggioni R, et al. (2010). Genetics of two marine shrimp hatcheries of the Pacific white shrimp Litopenaeus vannamei (Boone, 1931) in Pernambuco, Brazil. Cienc. Rural 40: 325-331. https://doi. org $/ 10.1590 / \mathrm{S} 0103-84782010005000008$

Lin YR, Hung HC, Leu JH, Wang HC, et al. (2011). The role of aldehyde dehydrogenase and hsp70 in suppression of white spot syndrome virus replication at high temperature. J. Virol. 85: 3517-3525. https://doi.org/10.1128/JVI.01973-10

Liu J, Yu Y, Li F, Zhang X, et al. (2014). A new anti-lipopolysaccharide factor (ALF) gene with its SNP polymorphisms related to WSSV-resistance of Litopenaeus vannamei. Fish Shellfish Immunol. 39: 24-33. https://doi.org/10.1016/j. fsi.2014.04.009

Lo CF, Leu JH, Ho CH, Chen CH, et al. (1996). Detection of baculovirus associated with white spot syndrome (WSBV) in penaeid shrimps using polymerase chain reaction. Dis. Aquat. Organ. 25: 133-141. https://doi.org/10.3354/dao025133

Luvesuto E, Freitas PD and Galetti-Junior PM (2007). Genetic variation in a closed line of the white shrimp Litopenaeus vannamei (Penaeidae). Genet. Mol. Biol. 30: 1156-1160. https://doi.org/10.1590/S1415-47572007000600021

Maggioni RM, Coimbra MRM, Costa RB, Diniz FM, et al. (2013). Genetic variability of marine shrimp in the Brazilian industry. Pesqui. Agropecu. Bras. 48: 968-974. https://doi.org/10.1590/S0100-204X2013000800023

Mello CC, Delsol GYL, Motte E, Escobar VAC, et al. (2011). Selection of shrimp breeders free of white spot syndrome and infectious hypodermal and hematopoietic necrosis. Pesqui. Agropecu. Bras. 46: 531-537.

Morano KA (2007). New tricks for an old dog: the evolving world of Hsp70. Ann. N. Y. Acad. Sci. 1113: 1-14. https://doi. org/10.1196/annals.1391.018

Moss SM, Moss DR, Arce SM, Lightner DV, et al. (2012). The role of selective breeding and biosecurity in the prevention of disease in penaeid shrimp aquaculture. J. Invertebr. Pathol. 110: 247-250. https://doi.org/10.1016/j.jip.2012.01.013

Nei M (1977). F-statistics and analysis of gene diversity in subdivided populations. Ann. Hum. Genet. 41: 225-233. https:// doi.org/10.1111/j.1469-1809.1977.tb01918.x

Peakall R and Smouse PE (2012). GenAlEx 6.5: genetic analysis in Excel. Population genetic software for teaching and research--an update. Bioinformatics 28: 2537-2539. https://doi.org/10.1093/bioinformatics/bts460

Perez-Enriquez R, Hernández-MartínezF and Cruz P(2009). Genetic diversity status of White shrimp Penaeus (Litopenaeus) vannamei broodstock in Mexico. Aquaculture 297: 44-50. https://doi.org/10.1016/j.aquaculture.2009.08.038

Robinson NA, Gopikrishna G, Baranski M, Katneni VK, et al. (2014). QTL for white spot syndrome virus resistance and the sex-determining locus in the Indian black tiger shrimp (Penaeus monodon). BMC Genomics 15: 731. https://doi. org/10.1186/1471-2164-15-731

Rousset F (2008). genepop'007: a complete re-implementation of the genepop software for Windows and Linux. Mol. Ecol. Resour. 8: 103-106. https://doi.org/10.1111/j.1471-8286.2007.01931.x

Sambrook J, Fritsch EF and Maniatis T (1989). Molecular Cloning: A Laboratory Manual. $2^{\text {nd }}$ Ed. Cold Spring Harbor Laboratory Press, New York.

Santos RN, Varela APM, Cibulski SP, Lima FES, et al. (2013). A brief history of White Spot Syndrome virus and its epidemiology in Brazil. Virus Rev. Res. 18: 1-7. https://doi.org/10.17525/vrr.v18i1-2.63

Senapin S, Phewsaiya K, Briggs M and Flegel TW (2007). Outbreaks of infectious myonecrosis virus (IMNV) in Indonesia confirmed by genome sequencing and use of an alternative RT-PCR detection method. Aquaculture 266: 32-38. https://doi.org/10.1016/j.aquaculture.2007.02.026

Shekhar MS and Ponniah AG (2015). Recent insights into host-pathogen interaction in white spot syndrome virus infected penaeid shrimp. J. Fish Dis. 38: 599-612. https://doi.org/10.1111/jfd.12279

Srivastava P (2002). Roles of heat-shock proteins in innate and adaptive immunity. Nat. Rev. Immunol. 2: 185-194. https:// doi.org/10.1038/nri749

Genetics and Molecular Research 16 (2): gmr16029668 
Vignal A, Milan D, SanCristobal M and Eggen A (2002). A review on SNP and other types of molecular markers and their use in animal genetics. Genet. Sel. Evol. 34: 275-305. https://doi.org/10.1186/1297-9686-34-3-275

Yu Y, Wei J, Zhang X, Liu J, et al. (2014). SNP discovery in the transcriptome of white Pacific shrimp Litopenaeus vannamei by next generation sequencing. PLoS One 9: e87218. https://doi.org/10.1371/journal.pone.0087218

Zeng D, Chen X, Li Y, Peng M, et al. (2008). Analysis of HSP70 in Litopenaeus vannamei and detection of SNPs. J. Crustac. Biol. 28: 727-730. https://doi.org/10.1651/08-3019.1

Zhao X, Guo L, Zhang Y, Liu Y, et al. (2012). SNPs of hemocyanin C-terminal fragment in shrimp Litopenaeus vannamei. FEBS Lett. 586: 403-410. https://doi.org/10.1016/j.febslet.2011.12.038

Genetics and Molecular Research 16 (2): gmr16029668 